\title{
Uniting Christian Students' Association's pilgrimage to overcome colonial racism: A southern African postcolonial missiological dialogue
}

\author{
Author: \\ R.W. (Reggie) $\mathrm{Nel}^{1}$ \\ Affiliation: \\ ${ }^{1}$ Department of Christian \\ Spirituality, Church History \\ and Missiology, University of \\ South Africa, South Africa

\section{Correspondence to:} \\ Reggie Nel \\ Email: \\ rwnel@unisa.ac.za \\ Postal address: \\ PO Box 392, University of \\ South Africa 0003, \\ South Africa \\ Dates: \\ Received: 30 Mar. 2015 \\ Accepted: 30 Sept. 2015 \\ Published: 14 Dec. 2015 \\ How to cite this article: \\ Nel, R.W., 2015, 'Uniting \\ Christian Students' \\ Association's pilgrimage \\ to overcome colonial \\ racism: A southern African \\ postcolonial missiological \\ dialogue', Verbum et Ecclesia \\ 36(1), Art. \#1454, 8 pages. \\ http://dx.doi.org/10.4102/ve. \\ v36i1.1454 \\ Copyright: \\ (C) 2015. The Authors. \\ Licensee: AOSIS \\ OpenJournals. This work is \\ licensed under the Creative \\ Commons Attribution \\ License.
}

\section{Read online:}

World Christianity has been enriched by Christian student movements such as the Uniting Christian Students' Association (UCSA) from South Africa. This article, based on my recent doctoral research, starts with the affirmation of the ambiguous relations of these movements with colonial racism. However, faced with new challenges in a postcolonial context, there are key impulses to be gained by an inter-subjective, but also interdisciplinary dialogue with these movements as they negotiate their calling. By focussing on one movement within the southern African context, UCSA, in particular its formation and development since the demise of apartheid in South Africa, the article aims to present an attempt to understand the missionary praxis of UCSA through a postcolonial missiological matrix. The article draws on the theological disciplines of missiology, systematic theology, church history, contextual theology, as well as the methodologies in non-theologic disciplines like sociology, in particular social movement studies, and history. The findings show, amongst others, a growing complexity in relation to its agency, how it frames its world and also how it used its authoritative sources to discern its calling. The article closes with some key insights and pointers relevant for faith communities in their mission to overcome colonial racism.

Intradisciplinary and/or interdisciplinary implications: The teaching and research in missiology and systematic theology in how the challenge of colonial racism is addressed, methodologically.

\section{Introduction}

The various Christian student movements (SCMs), also those from southern Africa, have an ambiguous relationship with colonialism. Potter and Wieser frame the origins of these SCMs in terms of what they call 'the great century of the expansion of Christianity throughout the world' (Potter \& Wieser 1997:1). Boyd, in writing up the history of this movement, also declares:

The Student Christian Movement (SCM) - with its varying names in many countries - and the World Student Christian Federation (WSCF) of which it is a part, can claim to be one of the major movements which have changed the course of the Church, and enriched its life, in the past three centuries. (Boyd 2007:1)

Whilst the formation of these movements of Christian students is to be found within the heyday of colonial (missionary) expansion and serving this expansionism, there is another side. At least from a southern African perspective, former leaders within the various SCMs, such as Beyers Naude, Cyril Ramaphosa, Allan Boesak and David Bosch as well as theological and public leaders all over the world, in particular in the struggle to overcome colonial racism, have inspired students. This struggle to overcome racism however, seems to be as critical as ever.

Recently, two female students at a prestigious university in South Africa caused heated outrage when they went to a costume party dressed up as black domestic workers (Mgcaba 2014). The principal of another university, Professor Jonathan Jansen, responded in a newspaper column to this incident, referring to a leading scholar in whiteness calling it, 'an opportunity for a racist joke without the burden of words' (Jansen 2014). Students from other universities, like the University of Cape Town and Rhodes University, often referred to as 'progressive' universities in the time of the struggles against apartheid, are at the time of writing protesting against what they deem to be vestiges of colonial racism, institutionalised in the symbols on their campuses. The struggle to overcome colonial racism amongst students seems to remain as crucial as ever.

The question is whether scholarly research, in particular for this article, theology and its disciplines of missiology, systematic theology, church history and contextual theology - also sociology, in particular 
social movement studies - still attend to the challenge of colonial racism, also manifested amongst younger people (the so-called 'born-frees') and in their living spaces like educational institutions. Is it possible to craft a dialogue with the movements of students, or (at least) with those working with these younger people and students responding to these challenges? In this article, I present findings from my doctoral research (Nel 2013), which aimed to take up this challenge to understand the missiological praxis of specifically one of these SCM affiliates from southern Africa, namely the Uniting Christian Students' Association (UCSA). This is carried out in terms of what I call a postcolonial missiological matrix (Nel 2013:197). The postcolonial missiological matrix, as a dialogical methodology, addresses the complexities of religious movements in terms of a new social movement perspective (Larana, Johnston \& Gusfield 1994; Leffel 2007; Tarrow 1998). In terms of this methodology I focus on the dimensions of how these movements speak of and reflect on themselves, and also, on whose behalf and with whom and how they define their boundaries. Influenced by this the key question is how these movements would frame and understand their world rhetorically. In other words, what are the challenges or opportunities they 'see' and respond to, and in terms of this, how do they read their authoritative sources in constructing and projecting their (missionary) calling, that is, their movement's culture or strategies.

The approach in this article is limited in two ways. Firstly, it focuses only on UCSA, although the author is aware of the various other SCMs in southern Africa who engage in this mission to overcome colonial racism. Secondly, the focus is on the period of UCSA's establishment and the first decade, between 1997 and 2007. The reason for these choices relate to the specific (colonial) history of South Africa and the manner in which colonial racism shaped this ministry in its establishment. I argue that this focus highlights the broader significance of and shifts within UCSA, especially in its witnessing pilgrimage to overcome colonial racism in South Africa. These reflections are structured within a broad overview of the road towards the unification initially, and some summative reflections and conclusions at the end.

The article therefore unfolds as follows. Firstly, I present the relevant theoretical and methodological considerations on the basis of which the particular missiological dialogue is built. After this theoretical section a narrative description of the processes leading up to the formation of UCSA follows. Following on that, I focus particularly on the various dimensions of the postcolonial missiological matrix, as indicated earlier. The article concludes with brief insights gained from this missiological dialogue in order to respond to the lingering challenges of colonial racism in the southern African students' context. The approach that I follow here has, however, a particular history.

\section{Understanding youth and student ministries}

Student and youth ministries have traditionally been studied theologically through the discipline of practical theology. However, one has to ask whether the current discourses within practical theology in relation to the subdisciplines of Christian education and youth ministry consciously address the questions of colonial racism, and the witnessing role of Christian youth and students themselves. In my thesis (Nel 2013:14-17), I show that a global shift on youth ministry as practical theology (Dean 2003, 2010; Nel 2003; Roebben 2005:23-32; Root \& Dean 2011; Ward 2008; White 2004:77-96, 2005), does not merely indicate a search for more effective ways of communicating the gospel to younger generations, but incorporates a thrust toward acknowledging and seeking to discern and articulate a theology of and by children and youth. This is a welcome development. Whilst these scholars work from different theological paradigms, and differ in their approaches, what is new in the emphasis that has just been described, is the quest to affirm the unique and valid capacities of young people and students, to experience and interpret their authoritative texts and their faith in terms of their own life-world. However, most work is carried out outside the African regions. In this article, I aim to understand how a southern African movement, UCSA, understood and responded to this phenomenon, that is, their witnessing (missional) intention. Further, my working definition of colonial racism is informed by the work of social activist and student leader, Steve Biko ([1978] 2006).

Biko argues that the notion of colour was introduced with an economic intent ([1978] 2006:96; see also Nolan 1988:70-75; Terreblanche 2002:239f.; Van der Westhuizen 2007:14-15, 53). Biko explains further: 'The racism we meet does not only exist on an individual basis; it is also institutional to make it look like the South African way of life' (Biko [1978] 2006:97). The present article, by focussing on UCSA, starts to address the question of what has happened in this context amongst youth ministries within faith communities from the global south in relation to this institutional reality. My intention here is to read and understand the official practices of specific Christian organisations as social movements, responding to an oppressive system, rather than to emphasise individuals as exceptional or mavericks. In my thesis (Nel 2013:160f.) I, therefore, argued that Biko's activism, as a South African student leader, and much later, Sugirtharajah's work as a postcolonial biblical scholar (Sugirtharajah 1999:229-240, 2001, 2003; see also Segovia 1999:177-195), is critical to take further the traditional approaches within theology on youth and student movements. Sugirtharajah shows that what is new in current anti-imperial contestations (also in theological research), meaning the shift from an 'anti-colonial mode', is that a postcolonialist understanding seeks to go beyond mere essentialist, binary and contrasting ways of thinking, which remain prevalent in the anti-colonialist tradition:

The task of theologians is not to change the world but to understand it. Theology does not create revolution; it changes people's perceptions and makes them aware of the need for revolution. Its function is to make people see more, feel more, and rekindle the fire of resistance. (Sugirtharajah 1999:236, [emphasis added])

A postcolonial understanding would therefore seek a 'radical syncretising of each opposition' (Sugirtharajah 2003:15). 
We can recognise this already in the thinking of Biko, as he addressed colonial racism and reveals various dimensions of consciousness and identity, cultural exchange and mixing, in an attempt to forge a critical and 'profitable syncretising' (Mangcu 2008:2-3; Sugirtharajah 2003:16). While Biko did not use the words 'profitable syncretising' of Sugirtharajah and Mangcu, he meant the same process which means that both the colonised and coloniser are in need of liberation towards a new humanity (Biko [1978] 2006:108). For the colonised, this means radical liberation from the structural and spiritual poverty that leads to self-hate and dependency, towards self-conscious transformative praxis (Biko [1978] 2006:3031, 52-53, 101-102). For the coloniser, this means liberation from imperialist, racist identifications, representations and institutions (Biko [1978] 2006:27; see also Mangcu 2008:2-3). As indicated in Biko's transformative praxis, one can also see the salience of various and more complex dimensions of identifications, as he keeps the different streams of contestation. The postcolonial turn as argued here, does not, however, become a new umbrella term for all that is black, youth, feminist or belonging to whatever other perspective not considered within the colonial discourse. Punt warns that this postcolonial turn does not mean a new hegemonic paradigm or label taking over, when he states:

The use of postcolonial as a catch-all can make it impervious to addressing the specifics of the past as the present, and so become an imperialist metanarrative itself ... it is given with the dialectic of colonial and imperial experience that projects of resistance and emancipation are disparate rather than harmonious, diverse rather than uniform, postcolonial. (Punt 2003:62)

I argue that, within a postcolonial framework, questions should be asked that reach beyond an anti-colonial or resistance set of binaries, because now we aim to understand the finer nuances of the contestations and varied interactions between the colonised and coloniser, as indicated in the term 'postcolony' (Mbembe 2001; Maluleke 2007: 503-527). The one cannot be understood without the other. Our readings of texts, but also the context as a text, are carried out by considering the two together, but with awareness of the gaps, collusions and contestations (Sugurtharajah 2003:16). As Biko suggested, the history of the silenced needs to be heard in dialogue with that of the dominating categories. In his argument the silenced are the perspectives and questions of the black, the laity and the young people, whilst the dominating categories would be the white people, the ministers and professional theologians, or the older generations. The distortions of history, based on power configurations, are addressed through the re-telling of the histories and tradition by those who were silenced, also in the face of the agents and narratives of the powerful. Further, the process of re-telling takes on communal modes of interaction, where the notion of inter-subjective dialogue is important. Understanding youth and student movements within this postcolonial matrix, indeed becomes a communal process, and also an exercise in solidarity. It is upon these considerations that I developed the postcolonial missiological matrix with a view to understanding youth and student movements. (For a more extensive explanation of this postcolonial missiological matrix see Nel 2013:140-198, 2014).

\section{Methodological considerations}

Asin practical theology (Cochrane, DeGruchy \& Petersen 1991; Pieterse 2011:720-721), there are different methodological approaches in missiology (Bevans \& Schroeder 2009; Karecki 2005:159-173; Leffel 2007; Wijsen 2005:129-147). In this research project, I followed a qualitative, emerging approach. Although I appropriated insights from the grounded theory approach, in particular from the trajectory of Strauss and Corbin (1990), this remained a missiological study; it is about the witnessing intention of the relevant movement in a particular context, studied through a particular methodology. Social scientific insights are helpful, yet Wijsen is correct when he argues that the approach of Holland and Henriot ([1983] 1992), called the praxis cycle, indeed 'helps to develop grounded theories in theology' (Wijsen 2005:130). Wijsen suggests a design that includes the elements of 'participatory objectification', 'analysis of symbolic power', 'correlation or confrontation' and 'empowerment of the people'. I explained and substantiated my appropriation of these stages in more detail in various chapters of my thesis ( $\mathrm{Nel} 2013$ ).

In the gathering of data for this study to understand the origin of UCSA, I spent time directly participating in its activities, observing, reading, listening and asking critical questions. This was carried out as a member of and in dialogue with the official discourses within the respective national executive committees. In addition, I combined this with an analysis of recorded conversations with some of the elected leaders of these committees about their praxis, especially those leaders who were involved in the establishment of this ministry. I also made extensive use of official documentation and processes within this movement and also my personal reflections on these. By making use of these methods of gathering data I was trying to understand UCSA in dialogue with the current conversations within the theological and relevant social scientific disciplines. Therefore, I did not simply tell the story of UCSA, but relate the story to the specific questions emerging from my postcolonial missiological matrix. In this process, I map and develop a 'thick description' of the praxis of UCSA within the aforementioned years. I then identified and named the emerging themes, which led to key concepts and eventually to a missiological framework by which these movements understand their specific mission in responding to the colonial reality in southern Africa. Through the constant comparative method, I subsequently related these emerging impulses to the current scholarly debates. In this, my aim was to correlate the impulses 'from the ground', with the literature. In the language of qualitative research, such correlation is a form of literature control, which in the missiological praxis cycle would constitute theological reflection. Wijsen (2005:118) argues convincingly that this correlation must also include the possibility of confrontation, meaning, challenging and changing our existing praxis as well as our theories about praxis.

Throughout this study, I moved between, on the one hand, immersion and participation in the movement and, on the other hand, the position of being reflective, constantly 
interpreting and comparing insights with literature until saturation point was reached. This methodology implies periods of gathering, reflection, analysis and interpretation of data, according to the constant comparative method (Glaser \& Holton 2004). It also assumes what Wijsen calls, 'researchafter-action' (2005:142-143). Although critical distance between me and the case has been assumed throughout this project, this distance has grown more as a result of particular dimensions of the research process, for example the dimensions of conceptualisation and the formulation of new insights and frameworks in dialogue with the community of scholarship. The nature of this type of qualitative research presupposes the possibility of having to stay 'in the field' for longer periods or even the possibility of shorter periods, depending on whether theoretical saturation is reached, but also the distance of critical reflection. Hence, there remains an ongoing relationship between the participant researcher and the action, even if it is a critical relationship. When reading the reporting on this research, one might gain the impression that it came about by means of a linear step-bystep method. But although such a methodical procedure is necessary for managing the project, underneath this form of articulation and production, there was a messy, iterative to-and-fro movement, which might be better expressed as a dance to the beat of the missiological remixes.

The next section of the article then presents the key findings from the study using this methodology. It starts with a brief outline of the processes behind the formation of UCSA, primarily on the basis of secondary sources.

\section{Understanding Uniting Christian Students' Association Towards a postcolonial ministry}

The South African Student Christian Movement (SCM) was birthed in the context of the 19th century 'revivals' within various Dutch Reformed Churches in South Africa (Conradie 1999:18; Nel 1983:93-98; Terblanche 1966:10-15). Colonial racism became a dominating factor in its development. Although a separate 'department' for coloureds (Erasmus 2001) was formed within SCM as early as 1940 (Van der Merwe 1996:77), the various separated and racially defined student associations came about through a process which started in 1951 and culminated in 1965 (Conradie 1999:42-61; Van der Merwe 1996:117-119). Through this separation, the Afrikaanse Christen Studentevereniging van Suid-Afrika (ACSV) (Afrikaans Christian Students Association of South Africa) for Afrikaans-speaking white people, the Students' Christian Movement of South Africa (SCM) for black Africans, the Students' Christian Association of Southern Africa (CSA) for the English-speaking white students, and the Christen-Studentebeweging van Suid-Afrika (CSB), (Christian Students Movement of South Africa) for coloureds were established. The latter later changed its name to Vereniging vir Christenstudente (VCS) (Association for Christian Students) (Conradie 1999:61). This separation on the basis of race and language happened under the pressure from, amongst others, the Nederduitse Gereformeerde Kerk (NGK) (Dutch Reformed Church) but also in terms of the particular colonial ideology of the time (Mangcu 2012:150-152; Van der Merwe 1996:117).

The establishment of UCSA in 1997 is, therefore, seen as a 're-unification'. The process of the re-unification between the VCS and ACSV, to form the UCSA (Verenigende Christelike Studente Vereniging), started formally with a meeting on 24 and 25 January 1992 in Stellenbosch between the various student bodies, including the Students Union for Christian Action (SUCA) and Scripture Union (SU). At this meeting a 'firm intent for unification' was agreed upon (Van der Merwe 1996:235) and the various stages were set out. It was affirmed that:

We repent of the unbiblical division that occurred in 1965. We commit ourselves to the vision of united ministry/movements in schools and tertiary institutions for the sake of our Christian witness in the world. (Van der Merwe 1996:235)

Formally, unification negotiations culminated in a unification conference in 1997. How we are to understand UCSA through the postcolonial missiological praxis is the critical question which I will attend to. I will focus, firstly, on the way UCSA reflected on its agency and self-consciousness, secondly, how it framed its world, and lastly, how it appropriated its authoritative sources. How does UCSA reflects on and speaks of itself?

\section{Agency and self-consciousness}

UCSA speaks of itself as a 'uniting' ministry, a 'youth' ministry, 'crossing borders' or being at the 'cross-roads', and lastly as en entity 'transforming' itself. Its existence as self-consciously a uniting student ministry is indicated in its name, Verenigende Christen-Studente Vereniging van SuiderAfrika (Uniting Christian Students' Association of Southern Africa). The leaders interviewed indicated that they wanted to walk an eenheidspad (road of unity). It was this eenheidspad which influenced the key decisions and processes in relation to its programmes, staff appointments and expenditures. During a personal interview on 11 August 2011, Reverend Collin Goeiman, the first co-chairperson of UCSA explains the evangeliese opdrag (evangelical command) to be one of the key drivers of embarking on this road as follows:

Natuurlik, ek dink, met die gees van die tyd het dit baie te doen gehad, demokratisering van die land, die, daar was 'n groot aandrang dat die apartheid strukture eintlik heeltemal moet val en ons kan nie meer voortgaan daarmee nie. Ek dink dit het natuurlik ander stukrag gegee, maar ek dink baie sterk was die evangeliese opdrag gewees, die kwessie rondom, dat hulle een moet wees. So, uhm ... ek dink dit was een van die sterk motiverings ...

During a personal interview on 23 August 2011 with Dr Vic Brink, the first administrative head, he stated that this represented a deep repentance from the sinful separation according to the Bible and a commitment to this nuwe pad van eenheid (new road of unity). Brink also made it 
clear that the process started before there was any political pressure to unite.

UCSA also sees its role as working primarily with youth, with students. In my own participation in activities, I observed that leaders and the staff often stated that they felt called towards this youth ministry. It is significant that the young people, who are mostly learners or students in primary and high schools are called either die jeug (the youth), or maats (mates), mostly by the members from the former VCS; on the other hand, die kinders (the children, or the kids), mostly by the members from the former ACSV. One has to give the leadership credit for consciously and purposefully implementing specific processes for transcending this divide by forging a new culture, what they called kruiskultuur (crossculture).

The notion of borders, and crossing these has been running through the self-understanding of UCSA since its inception. In 1998, the year after the merger, the annual theme was kruiskultuur (cross-culture). Through Bible studies and activity guides called Die X-Faktor (the X-Factor) (Brink \& Brink 1998), as well as t-shirts and other products, the idea of UCSA embodying kruiskultuur was nurtured throughout the organisation. This emphasis on 'cross-culture' is interpreted with the symbol of the cross of Jesus Christ seen as the central source to address cultural difference and the cultural shocks that came about as a result of the merger in the 'New South Africa'. The name is also an innovative play on words, because it incorporates the notion of influencing youth culture, where the cross of Jesus is now central, thereby inducing a new subculture. Brink and Brink explain:

Die CSV en VCS het in 1997 verenig om die VCSV te vorm. Die vereniging sal in 1998 grond toe geneem word - na die takke. Die woordspeling wat ons wil gebruik is: kruis-kultureel. Ons wil julle uitdaag en toerus om binne die nuwe uitdagings in ons land die eerste treë te neem om mense van ander kulture te leer ken en waardeer. En laastens wil die VCSV die gewone kwessies van jongmense hanteer en daarom vir julle help to cross barriers. (Brink \& Brink 1998:6)

The Reverend Don Sauls, the first Mede-Uitvoerende Hoof (co-executive head) with Revd Cassie Carstens, during a personal interview on 23 August 2011, however, lamented the fact that this cross-cultural process was not taken further because of budgetary constraints. This suggests that the challenge towards a new culture, even a kruiskultuur is not easy, and not a once-off event.

In the period after the turn of the millennium, it seemed as if the understanding of UCSA with a kruiskultuur had shifted slowly towards a discourse of 'transformation'. This meant not only to focus on changed lives, but also a changed organisation and changed communities. Although the notion of UCSA as a youth ministry remained central, leaders and staff started, however, to refer more to the shifts in the emphasis from the youth ministry towards a transformation or change, 'back to the basics'. A conscious, in-depth conversation on this was sparked by a discussion document, submitted at the national executive meeting in November 2007 by senior staff members. This referred specifically to the challenge of transformation within the organisation, and, in general their experience of working within UCSA (Minutes of National Executive Committee, 23 November 2007a). Subsequently through organised sessions of dialogue and broad visioning processes, it was stated that UCSA should start to project itself as the space to skep lewensveranderende ervarings vir jongmense (create life-transforming encounters for the youth). These shifts and interplay between different themes also relates to how UCSA framed its context.

\section{Framing the context}

From the research conducted, it emerged that the UCSA remained conscious of the times they were living in. Goeiman, during a personal interview on 11 August 2011, spoke of the gees van die tyd (the spirit of the time). However, at various times, there were different viewpoints and contestation of how the gees van die tyd was discerned. From the various themes that emerged from the fieldwork, the formation of UCSA was framed in terms of it being in a 'uniting country', being 'compassionate to the poor and needy', but then also, becoming aware of the 'transforming' realities. In the subsequent sections I shed more light on these themes.

At the formation of UCSA, the leaders interviewed saw their existence in terms of the quest for primarily dismantling the apartheid-shaped Christian student ministries of the time. Carstens, first co-executive head with Sauls, already stated in the early 1990s:

In die volgende vyf tot tien jaar sal ons ' $n$ omskakeling van baie dinge sien. Ons is van God gestuur met 'n taak en opdrag in hierdie wêreld ... Die ACSV moet die evangelie uitdra in hierdie tyd, en help vorm aan die nuwe Suid-Afrika en die nuwe wêreld. (Van der Merwe 1996:208)

This focus area was also emphasised by Goeiman in the context of the pressure to unite. He refers to this as the 'democratisation of the country' and the groot aandrang dat die apartheid strukture eintlik heeltemal moet val (big insistence that the apartheid structures actually must eventually fall totally).

However in this respect, being in a uniting country meant that they felt that the UCSA could not escape the reality of poverty and inequality. The UCSA, therefore, made another critical shift, to a position where they explicitly aimed at serving the needs of the poor and needy. In this regard, one can refer to the work of the Joshua Student Movement (JSM) envisioned as its outreach, service and witness division. JSM explained itself in its slogan to, 'Mobilise, Encourage, Train and Engage the youth to be relevant to the Poor and Needy and to reach out to a broken world' (brochure for JSM Marketing). Questions are then asked of the young people: 'Ervaar jy deernis (compassion) vir mense (met verskillende behoeftes) maar weet nie wat om te doen nie?', and, 'As jy iets wil doen en van jouself en jou tyd wil gee, wil die Joshua Studentebeweging jou die geleentheid gee om wel ' $n$ verskil te maak' (Brink \& Brink 1998:12). 
The notion of 'poor and needy' is framed here in holistic terms. 'Needy' could be understood personally, meaning praying for 'own needs', but also for 'the needs of their friends and the lost' (brochure on Joshua Triplets). The need to redefine the 'poor and needy' in terms of the real economic realities became more important, also with regard to the finances of the movement itself. In a finance committee report it is later stated that 'Armoede het die afgelope 10 jaar gestyg. Ons moet die uitdagings van ons tyd identifiseer.' (Poverty has escalated over the last 10 years. We have to identify the challenges of our time) (UCSA). (Minutes of the finance committee 13 November 2007b).

This framing of the world in terms of the economic realities, therefore, made way for a greater emphasis on 'transformation'. Van der Merwe (1996:237) speaks early on about the transformasie proses (transformation process) in the context of the re-unification between 1992 and 1997. This takes place at a time in the 1990s when transition and transformation were key narratives within the country. Also for the VCS the issue of transformation was critical in relation to the appointment of staff, and organisational culture (personal interview with Goeiman on 11 August 2011). Hence, for members from the former VCS, it meant representation in terms of staff appointments and the affirmation of volunteers in the ministry in alignment with government's policy on transformation. Whilst there are, however, no clear dividing lines for members of the former CSV, transformation or what they preferred to call verandering (change) was personal and spiritual.

Much of this tension in relation to transformation has been in terms of the different understandings and experiences, but also, as Sauls noted in the personal interview on 23 August 2011, different theological traditions, which emphasise the growing complexity in how the world of members is framed, and more importantly how they read and try to follow its authoritative sources. This is the section I turn to next.

\section{Reading its authoritative sources}

From its inception, the UCSA aimed at grounding its actions on the Bible. All events would invariably start with a reading from the Bible and at least some reflections together on the text. UCSA's relationship and therefore usage of the Bible cannot be seen separately from its broader affiliations and historical development as an association.

Bible study guides and activity guides played a key role. These kringe (study circles) and sermons were embedded in times of 'praise and worship', as well as dance productions developed and performed by the Diensjaar vir Christus (service year for Christ) teams. It is in terms of these forms of study, that I reflect on the readings of the Bible in UCSA, starting off with the emphasis on the cross.

In articulating the call, this biblical symbolism of the 'cross' came out strongly in the Bible studies, and also the fears and price of entering into the merger. Whilst this symbol spoke of sacrifice, it also spoke of commitment and obedience in the context of following Jesus. After the unification in 1997, new Bible study material was developed which would serve the process of the merger. In this respect, I have already referred to the focus on the cross in particular through the Bible study of Die X-Faktor. The aim through this guide was to 'take the unification in 1998 to the ground - to the branches' (Brink \& Brink 1998:6). In these studies, it was also noted that the characteristics of kruis-kultuur were actually the characteristics of the followers of Jesus (1998:7).

However, the focus was also on the life of Joshua (in line with the work of the JSM) as discussed previously. The process of this Bible study was as follows. The participants read a verse from the Bible, for example on Joshua, with a leidraad (clue) and asked to fill in their responses and indicate their commitments. In the next study, the focus would be on crossing the river Jordan (like Joshua). Again the same pattern would be followed with a verse from the Bible, and then questions, firstly, what was the promise for Joshua, and later what the promise was for the participant as an individual to be able to pursue the plan God has for him or her.

These examples indicate the way that the Bible was studied in order to address the challenges that UCSA grappled with as the shifts in agency and the way they framed their world became inevitable. What is important is the notion to carry your 'cross', 'crossing-over' or 'entry into the new land' as the initial defining metaphors for the discipleship in the 'New South Africa' and the new uniting movement. In line with this crossing of borders emerged, lastly, a notion of the transformation of self, the ministry and also their communities.

\section{Conclusion}

In this article, I indicated my research findings on how the UCSA started its journey in terms of a compelling vision and imperative to be a movement with a specific calling. In a uniting country, South Africa, this calling was understood to be the structural unification of apartheid-shaped student ministries.

From the research on which this article is based, it emerged firstly, that the calling to unify in this geopolitical region was becoming more complex. The unification narrative from colonial identifications, like ASCV and VCS, important as it was, could not anymore be reduced to racial or organisational identifications only. The constantly developing reality, relating not only to the challenges of the poor and needy, but also to transformation, suggests new innovations; what I have called 'new blends' (Nel 2013:310). In terms of these blends, one can refer to the challenge that the UCSA had to respond to through the emphasis on 'cross-culture', the Joshua and cross symbolism, as well as by self-consciously creating 'new transformative encounters'. Whilst the issues of race cannot be discarded altogether, this emerging complexity, I would suggest, points rather to a deepening of the discourse and, therefore, concrete practices that directly relate notions of crossing borders and transformation with each other. The 
postcolonial notion of syncretism or what I called 'remixing' (Nel 2013:310) now becomes critical. The spaces for these encounters need to be nurtured consciously.

Secondly, it seems this challenge of a growing complexity is not simply to be addressed through more leadership training in terms of the existing (neo-colonial) models of the organisations. What the findings point to is perhaps much deeper and theological in nature. It resonates with the challenge that White (2005) aims to address, as he proposes 'a transformative youth ministry approach' through 'practising discernment with youth'. White affirms the agency and social construction of youth, as I have written in this article. In a transformative approach to youth or students ministry, the question is whether formation into a body or movement of believers, will transcend the particular institutional and social heritage of the constituents. This question relates to the earlier reference to Biko's challenge. For Biko the fundamental challenge of 'spiritual poverty' in all its complexity, was much more than organisational maintenance, be it a Christian organisation or not. Hence, for him, the pending collapse of colonial institutions was inevitable, as students will resist this and move elsewhere in the quest for a society with a more human face. The findings from the study of the formation and development of the UCSA suggest how a road of transformation towards a postcolonial expression can open up the deeper contradictions within colonial structures under the surface, but, at the same time, address these contradictions as communities remain open to the context, and their authoritative sources.

Thirdly, it, therefore, makes sense that the findings in this limited study also point to a new quest for understanding the spiritual dimensions of this road. Such understanding has been shown to be important in the narratives of 'spiritual' transformation, mixed with the imperative for organisational and community transformation. This emphasis is relevant in the context of the need to address the challenge of spiritual poverty as the transformation of self, of the particular faith community and of the communities beyond. There is a real danger of fundamentalism when the spiritual dimensions are severed from the context of economic tension and financial constraints. Hence, the resurgent questions on finance and how to respond to the needs of young people and students in the concrete economic climate becomes critical in addressing the matters of 'spiritual growth' or faith development.

A fourth insight that arose as a concern for me was the lack of indications of what I would call an explicit African consciousness, at least in this dialogue with the official processes of re-unification. This movement remains a southern African ministry and one could argue that the UCSA does not need to state this explicitly. The question was, however, whether knowledge of this locatedness is enough to translate into practical involvement and reimagining of itself explicitly, in terms of the challenges faced by the continent. The practical involvement is critical in the light of the story of the young students in my introduction. Whilst there were periods where an outward focus to the 'poor and needy' in the southern African region was prominent (through the Joshua Student Movement), it remains important to raise this question on the perception of an inward orientation of the UCSA, subsequent to these isolated periods.

As the researcher, one, however, needs to concede, upon reflection, that a postcolonial dialogue of this nature, which assumes a thorough and respectful understanding of our dialogue partners does not end here. The insights from this dialogue remain preliminary and open to ongoing critique. Furthermore, this type of dialogue with the 'ordinary' members of uniting movements like the UCSA, or even with those not involved in these movements, the non-members, will be important to understand, in order to see, feel and 'rekindle the fire'.

The early formation and development of UCSA, as the organisation aspires to overcome a particular colonial racist legacy - although its actions may seem ambiguous - still seems to hold a promise to continue to enrich the ever new expressions of Christianity, and also those institutions which shape the lives of students. This dialogue is critical for the challenges students face and aim to address today.

\section{Acknowledgements Competing interests}

The author declares that he has no financial or personal relationship(s) that may have inappropriately influenced him in writing this article.

\section{References}

Bevans, S.B. \& Schroeder, R.P., 2009, Constants in context: A theology of mission for today, Orbis Books, Maryknoll, N Y.

Biko, S.B., [1978], 2006, I write what I like, Picador Africa, Johannesburg.

Boyd, R., 2007, The witness of the student Christian movement: Church ahead of church, SPCK, London.

Brink, V. \& Brink, T., 1998, Die X-Faktor: Bybelstudie en Aktiwiteitsgids vir VCSV-takke, VCSV van SA, Stellenbosch.

Cochrane, J.R., De Gruchy, J.W. \& Petersen, R., 1991, In word and deed. Towards a practical theology for social transformation, Cluster Publications, Pietermaritzburg.

Conradie, W.S., 1999, 'An analysis of the interplay between theological and political factors in the growth and split of the Student Christian Association of South Africa, with special reference to the role of the Afrikaners (1896-1965)', MA thesis, All with special reference to the role of the Afi
Nations Christian College, Hertfordshire.

Dean, K.C., 2003, 'The new rhetoric of youth ministry', Journal of Youth and Theology 2(2), 8-19. http: //dx.doi.org/10.1163/24055093-90000111

Dean, K.C., 2010, Almost Christian: What the faith of our teenagers is telling the American Church, University Press, Oxford.

Erasmus, Z. (ed.), 2001, Coloured by history, shaped by place: New perspectives in coloured identities in Cape Town, Kwela Books, Cape Town.

Glaser, B.G. \& Holton, J., 2004, 'Remodeling grounded theory', Forum Qualitative Social Research 5(2). http://www.qualitative-research.net/fqs/

Holland, J. \& Henriot, P., [1983], 1992, Social analysis: Linking faith and justice, 9th edn., Orbis, Maryknoll.

Jansen, J., 2014, 'Innocent joke, my backside', Times Live, viewed 19 August 2014, from http://www.timeslive.co.za/thetimes/2014/08/15/the-big-read-innocentjoke-my-backside

Karecki, M., 2005, 'Teaching missiology in context: Adaptations of the pastoral circle', in F.J.S. Wijsen, P. Henriot \& R. Meija (eds.), The pastoral circle revisited. A critical quest for truth and transformation, pp. 159-173, Pauline Publications, Nairobi.

Larana, E., Johnston, H. \& Gusfield, J.R., 1994, New social movements: From ideology to identity, Kindle edition, Temple University Press, Philadelphia.

Leffel, G., 2007, Faith seeking action: Mission, social movements, and the Church in motion, Scarecrow Press, Toronto. 
Maluleke, T.S., 2007, 'Postcolonial mission: Oxymoron or new paradigm?', Swedish Missiological Themes/Svensk Missions Tidskift 95(4), 503-527.

Mangcu, X., 2008, To the Brink: The state of democracy in South Africa, University of Kwazulu-Natal Press, Scotsville.

Mangcu, X., 2012, Biko: A biography, Tafelberg, Cape Town.

Mbembe, A., 2001, On the postcolony, Kindle edition, University of California Press, Los Angeles.

Mgcaba, S., 2014, 'Tuks get tough on \#blackface party picture', ENCA, viewed 14 August 2014, from http://www.enca.com/tuks-blackface-party-picture

Nel, M., 1983, Jeug en evangelie, NG Kerk boekhandel, Pretoria.

Nel, M., 2001, Jeugbediening: 'n Inklusiewe gemeentelike benadering, CLF, Bloemfontein.

Nel, M., 2003, 'Youth ministry as a practical theology: Making a case for youth ministry as an academic discipline', Journal of Youth and Theology 2(1), 68-83. http:// dx.doi.org/10.1163/24055093-90000205

Nel, R.W., 2013, 'Discerning an African missional ecclesiology in dialogue with two uniting youth movements', unpublished DTh thesis, Department of Christian Spirituality, Church History and Missiology, University of South Africa.

Nel, R.W., 2014, 'Discerning the role of faith communities in responding to urban youth marginalisation', HTS Teologiese Studies/Theological Studies 70(3), art. \#2743. http://dx.doi.org/10.4102/hts.v70i3.2743

Nolan, A., 1988, God in South Africa: The challenge of the gospel, David Phillip Press, Cape Town.

Pieterse, H.J.C., 2011, 'Die noodsaak van die verrekening van metateoretiese aspekte rakende ' $n$ hermeneutiese benadering tot die praktiese teologie', In die Skriflig 45(4), 719-737. http://dx.doi.org/10.4102/ids.v45i4.200

Potter, P. \& Wieser, T., 1997, Seeking and serving the truth: The first hundred years of the World Student Christian Federation, WCC Publications, Geneva.

Punt, J., 2003, 'Postcolonial Biblical criticism in South Africa: Some mind and road mapping', Neotestamentica: Journal of the New Testament Society of South Africa 37(1), 59-85.

Roebben, B., 2005, 'Light of day-scaffolding a theology of youth ministry', Journal of Youth and Theology 4(1), 23-32. http://dx.doi.org/10.1163/2405509390000125

Root, A. \& Dean, K., 2011, The theological turn in youth ministry, Kindle edition, IVP Books, Downers Grove.
Segovia, F.F., 1999, 'Postcolonial and diasporic criticism in Biblical studies: Focus, parameters, relevance', Studies in World Christianity 5(2), 177-195. http://dx.doi. org/10.3366/swc.1999.5.2.177

Strauss, A. \& Corbin, J., 1990, Basics of qualitative research: Grounded theory procedures and Techniques, Sage Publications, London.

Sugirtharajah, R.S., 1999, 'Postcolonialism and Indian Christian theology', Studies in World Christianity 5(2), 229-240. http://dx.doi.org/10.3366/swc.1999.5.2.229

Sugirtharajah, R.S., 2001, The Bible and the third world, Cambridge University Press, Cambridge.

Sugirtharajah, R.S., 2003, Postcolonial reconfigurations: An alternative way of reading the Bible and doing theology, SCM Press, London.

Tarrow, S., 1998, Power in movement: Social movements and contentious politics', Cambridge University Press, Cambridge.

Terblanche, D.J.M., 1966, 'The Ned Geref Kerk en sy naskoolse jeug', DTh dissertation, University of Stellenbosch.

Terreblanche, S., 2002, A history of inequality in South Africa 1652-2002, University of Kwazulu-Natal Press, Pietermaritzburg.

Uniting Christian Students' Association (UCSA), 2007a, Minutes of National Executive Meeting, 23 November

Uniting Christian Students' Association (UCSA), 2007b, Minutes of Finance Committee, 13 November.

Van der Merwe, G., 1996, Jesus is koning:Dieverhaalvan die Christen-Studentevereniging van Suid-Afrika, 1896 tot 1996, CSV van Suid-Afrika, Stellenbosch.

Van der Westhuizen, C., 2007, White power and the rise and fall of the National Party, Zebra Press, Cape Town.

Ward, P., 2008, Participation and mediation: A practical theology for the liquid Church SCM Press, London.

White, D.F., 2004, 'The youth theological initiative: An experiment in the pedagogy of communion', Journal of Youth and Theology 3(1), 77-96. http: //dx.doi.org/ 10.1163/24055093-90000276

White, D.F., 2005, Practicing discernment with youth: A transformative youth ministry approach, The Pilgrim Press, Cleveland.

Wijsen, F.J.S., 2005, 'The practical-theological spiral: Bridging theology in the West and the rest of the world', in F.J.S. Wijsen, P.J. Henriot \& R. Meijsa (eds.), The pastoral circle revisited. A critical quest for truth and transformation, pp. 129-147, Pauline Publications, Nairobi. 